\title{
Nasal Spray Dosage Form
}

National Cancer Institute

\section{Source}

National Cancer Institute. Nasal Spray Dosage Form. NCI Thesaurus. Code C91157.

A spray intended for administration to the mucosa of the nose. 